Brlás Georgina ${ }^{1}$ - Horváthné Kökény Annamária ${ }^{2}$

\title{
Pénzgazdálkodás, avagy az életciklusok megtakarításai a mindennapokban
}

\author{
Brlás, Georgina - Horváthné Kökény, Annamária \\ Financial Management, the Savings of Life Cycles in Everyday Life
}

Összefoglaló:

„A pénz mozgatja a világot” (BALYÓ, 2004, 3. p.) - gyakran elhangzó szlogen, mely valóban meghatározza életünket. Kisgyermekkortól hamar tudatosul mindenkiben, hogy az élethez elengedhetetlenül szükséges a pénz. Végigkíséri egész életünket. Életminöségünk attól függ, hogyan tudjuk a költségvetésünket úgy alakítani, hogy elegendő összeg jusson megtakarításokra is. A hétköznapi életben szükséges javakat meg tudjuk vásárolni, de úgy kell gazdálkodnunk, hogy a kitüzött céljaink megvalósításra kerüljenek. Életünk folyamán az egyéni és a közös célok meghatározóak. Nagy szerepe van a megfelelö, helyes döntésnek a pénzünk felhasználásában. Kiemelkedő jelentősége van a tudatosságnak, a megfontoltságnak, a precizitásnak és a naprakészségnek a tervezés során. A család minden tagjának az érdekeit és véleményét figyelembe kell venni. Amennyire csak lehetséges, a döntéseket közösen kell meghozni. Tanulmányunkban az öngondoskodás különbözö életciklusokban betöltött szerepét szeretnénk hangsúlyozni és az ehhez kapcsolódó primer kutatásunk eredményét bemutatni.

Kulcsszavak: pénzügyi kultúra, pénzügyi tervezés, megtakarítás, öngondoskodás, adókedvezmény

Abstract:

'Money rules the world' (BALYÓ, 2004, p. 3.) - it is an often used slogan which really determines our life. From an early age we realize how essential money is for us. It accompanies all our life. The quality of our life depends on how we can deal with our budget to be able to put aside as well. We can buy all the necessary items for everyday life but we have to manage well in order to be able to achieve our objectives, too. During our life our individual and common goals are also essential. The right and appropriate decisions have a great share in using our money. There is outstanding importance of being conscious, sober-minded, and precise and up-to-date during planning. We have to take into consideration the opinion of all the family members. Decisions need to be made together if possible. In this study we would like to emphasize the role of self-care in different life cycles as well as show the result of our related primary research.

Keywords: financial culture, financial planning, savings, self-care, tax benefits

\section{1. ÖNGONDOSKODÁS}

Az öngondoskodás napjainkban. Pénzügyeink

elengedhetetlen megtervezésével

\footnotetext{
${ }^{1}$ Főiskolai hallgató, Pénzügy-Számvitel szak Controlling szakirány, III. évfolyam, Bethlen István Szakkollégium Szolnoki Főiskola, 5000 Szolnok Tiszaligeti sétány 14.

${ }^{2}$ Főiskolai docens, Ph.D., Szolnoki Főiskola, Közgazdasági, Pénzügyi és Menedzsment Tanszék, 5000 Szolnok Tiszaligeti sétány 14 .

Lektorálta: Nagy Rózsa, közgazdaságtudományok kandidátusa, főiskolai tanár
}

célunk az, hogy megfelelő felkészültséggel álljunk a jövőbeni biztos, illetve bizonytalan események elé. Fontos tudnivaló ekkor, hogy mekkora összeget és milyen módon vagyunk képesek tartalékolni. Meg kell találni a legmegfelelóbb megtakarítási terméket: például biztosan bekövetkező események esetében megtakarításra alkalmas akár egy bankbetét; váratlan eseményekre pedig megfelelőek a különféle biztosítások. Manapság 
azonban nem könnyű feladat megtakarításokat felhalmozni, mivel az emberek a különböző életpályáikon más és más jövedelmi helyzetbe kerülnek. A pénzügyi öngondoskodás véleményünk szerint három részre bontható. Első a jövedelem megszerezése, második a jövedelem elköltése - fogyasztás, majd végezetül az el nem költött pénz felhasználása, befektetése. A fogyasztás során meg kell különböztetni a mindennapi élethez elengedhetetlen termékeket vagy szolgáltatásokat (például élelmiszer, lakhatás), valamint az olyan termékeket vagy szolgáltatásokat melyek átlagosnak mondhatóak, de nem bírnak létfontossággal; végezetül pedig a luxus termékeket is: például arany ékszer és a világkörüli utazás. Azonban ezek a jövedelemszinttől és a különbözó szükségletektől függően háztartásonként vagy akár személyenként is eltérőek lehetnek. Ez alapján hozhatóak meg személyre szabottan a kiadásokkal kapcsolatos döntések. Az öngondoskodás folyamatának kialakításában meghatározó az is, hogy milyen időtávban gondolkodunk: rövid (1 évnél nem hosszabb), közép vagy hosszú táv. Fontos, hogy milyen céllal, illetve célokkal, vagy hogy egyáltalán rendelkezünk-e konkrétan meghatározott célokkal. Emellett arra is oda kell figyelni, hogy mekkora az elvárható hozam: az az összeg, amit majd a pénzem használatáért kapok, és mekkora a kockázat, azaz mennyire bizonytalan számomra egy adott befektetés, mekkora a nyereség illetve veszteség aránya.

Napjainkban már nem is lehet kérdéses a takarékoskodás fontossága, mivel ezáltal találjuk meg helyünket a világban: így juthatunk például lakáshoz, autóhoz; így oldhatjuk meg nyaralásunkat; és így tudunk felkészülni a váratlan eseményekre is. Továbbá nyugodt időskort biztosíthatunk magunknak és családtagjainknak. Mindehhez fontos átgondolni bizonyos kérdések körét: milyen célra teszünk félre, mennyi időre tervezzük pénzünket befektetni és milyen feltételek mellett és mekkora összeget vagyunk képesek havonta erre szánni (PSZÁF, 2014).

\section{KÜLÖNBÖZŐ ÉLETCIKLUSOK VÁLTOZÓ CÉLKITŰZÉSEI}

Ez azonban nem korlátozható szoros keretek közé, hiszen egyénenként változó például az, hogy mikor válik valaki kereső személlyé, mikor végzi el az iskoláit, milyen jellegú és milyen bevételt jelentő munkaviszonyt tud létesíteni, tehát hol helyezkedik el az ember az élet hierarchiájában. Attól függetlenül, hogy ez nem mindenkire alkalmazható séma, mindenkinek ezeket a lépcsőfokokat kell megtennie az életben.

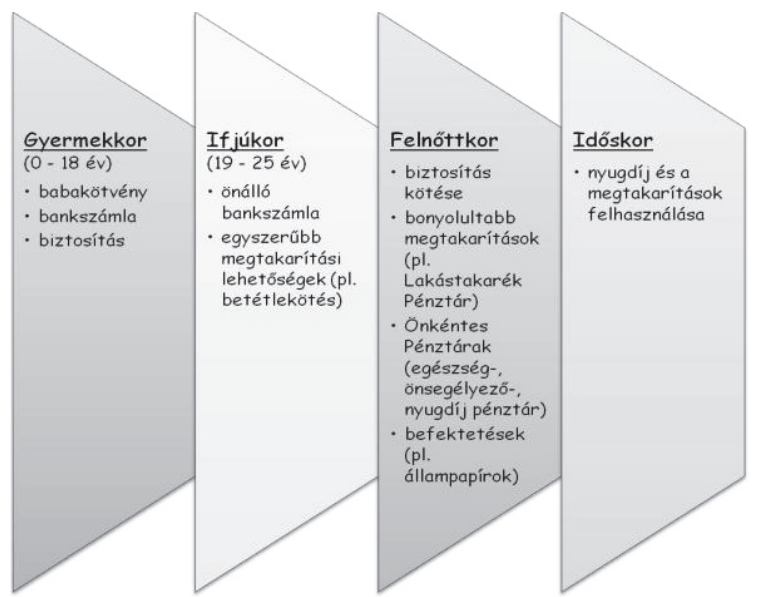

1. ábra: Az emberi élet nagyobb szakaszai 


\section{TAKARÉKOSKODÁS GYERMEKKORBAN}

A 0 és 18 év közötti korosztály megtakarítási lehetőségeit három irányból is megközelíthetjük, az állam, a bankok és a biztosítók szemszögéből.

Az állam által nyújtott megtakarítási forma

A BABAKÖTVÉNY, más néven életkezdési támogatás, melyet a fiatalok életkezdési támogatásáról szóló 2005. évi CLXXIV. törvény szabályoz. A Magyar Államkincstár által kezelt betétforma. 18 éves kor alatt bármikor megnyitható. A start-értékpapírszámla két részből áll: van egy ügyfélszámla, mely a befektetésre váró összeg nyilvántartására szolgál, és van egy értékpapírszámla, ami a befektetésekből származó értékpapír állományának nyilvántartását biztosítja. A számlára kerül az állami támogatás és az átutalt befizetés összege, ahol az nem kamatozik. Ahhoz, hogy kamatozzon is, megbízást kell adni a kincstár által forgalmazott értékpapír vásárlására, vagy jegyzésére. Ez egy állam által nyújtott támogatás, mely az egyéni befizetésekből és a hozamból tevődik össze. Kezdetben azon gyermekek részére volt köthető, akik 2005. december 31-e után születtek, magyar állampolgárságúak és Magyarország területén bejelentett lakóhellyel rendelkeztek. Ez azonban úgy módosult, hogy már a 2006. január 1. előtti születésűekre is nyitható start számla, de részükre nem jár az állam által nyújtott életkezdési támogatás összege. A befizetett összeg arányában állami támogatás kapható, de ez maximum évi 10 százalék vagy 6000 forint, kivéve: rendszeres gyermekvédelmi kedvezményre jogosult esetén ez az összeg 20 százalék vagy évi 12000 forint. Támogatások és a hozamok összege elhelyezhető állampapírokban, ami az állami garancia miatt hosszú távú befektetési lehetőséget biztosít. Éppen az állami garancia miatt hosszú távú és biztonságos befektetés. A számla vezetése, használata és a kifizetések is díjmentesek. A hozam és a megtakarítás után semmiféle adó-, illeték-, illetve járulék fizetési kötelezettség
A számlán felhalmozódott összeget a számla tulajdonosa tizennyolcadik életévének betöltését követően a törvényben meghatározott célokra veheti fel, melyek a következők: tanulmányok, pályakezdés, lakhatás, gyermekvállalás feltételeinek megteremtése, és egyéb meghatározott célok.

\section{Biztosító társaságok kínálata}

Minden szülőnek az az álma, hogy gyermekének gondtalan, anyagi problémáktól mentes felnőttkort biztosítson. Ennek egyik formája a megfelelő biztosítási forma igénybevétele, mely a rendszeres megtakarításon túl elfogadható hozam segítségével növelheti a befektetett alapösszeget. Számos biztosító cég számtalan megoldási lehetőséget nyújt. A szülő feladata, hogy megtalálja a gyermeke számára a legmegfelelőbbet.

Pénzintézetek szerepe a takarékoskodás terén Napjainkban a legtöbb bank már gyermekek számára is kínál szolgáltatásokat. Ez a pénzintézetek számára nagy lehetőség lehet, mivel elég nagy a valószínúsége, hogy évek múltán is a kiválasztott bankjuknál maradnak az addigra már felnőtt gyerekek. Ekkor említhető meg az első kapcsolat kialakítása a bankkal. A fiatalok számára megnyitható az úgynevezett junior számla (NBK, 2011), ami egy folyószámla. A folyószámla bankszámlaszerződés által jön létre, mely a szerződő pénzforgalmát bonyolítja le. Emellé általában igényelni lehet már bankkártyát is, amivel a számla felett rendelkezhet annak tulajdonosa. Ezek a számlák rendkívül alkalmasak a jövőben kívánt célok elérésének finanszírozására, mivel a számla összege befizetéssel bármikor növelhető és a számlán lévő összeg folyamatosan kamatozik. Ezen felül a számlavezetés a legtöbb banknál díjmentes. Legfőbb cél a takarékoskodás, valamint a gyermekek bevezetése a pénzügyek világába. Ez egy likvid, azaz bármikor hozzáférhető, szabad felhasználású megtakarítás. 


\section{AZ IFJÚSÁG MEGTAKARÍTÁSI LEHETŐSÉGEI}

A 19 és 25 év közötti korosztályhoz tartozók egy része valószínűleg még nem rendelkezik rendszeres jövedelemmel, de nyári- vagy diák munkákból, hétvégi- vagy éjszakai munkából, esetleg ösztöndíj által bevételhez juthatnak. Az egyéni kiadásaik azonban még jellemzően nem magasabbak a megszerzett bevételeknél, mivel a fiatalok többsége ilyenkor még a szülőkkel él, tehát általában anyagi támogatást tôlük kapnak. Így nincs rezsi költségük és élelmiszerre általában még nem ők költenek. A „feleslegessé vált" pénzt kisebb megtakarításokba tudják fektetni, melyek segítségével a kitűzött apróbb célokat saját erőből is el tudják érni. Mivel ennek a korosztálynak a bevételei még nem képviselnek olyan jelentős összeget, mint esetleg majd a felnőtt korukban, ezért inkább a kockázatmentességre és ezáltal a kisebb hozamra törekednek. Éppen ezért ebben az életkorban leggyakrabban az egyszerúbb megtakarítási formák kerülnek előtérbe: például bankszámlanyitás, megtakarítási számlavezetés, betétlekötés ${ }^{3}$. Ezek a pénzügyi termékek felhasználásukat tekintve általában a közeljövőben elérendő célok kielégítésére szolgálnak: például tanulmányok vagy albérlet finanszírozása (PSZAF, 2013).

\section{Az aktív felnőttkor el nem költött pénzei}

Költségvetés készítésével könnyen átláthatóvá válik, hogy mire elég a családban élők jövedelme, mire kell költeni mindenképpen. Mérlegelni kell, mi az, ami kevésbé fontos a mindennapi megélhetéshez.

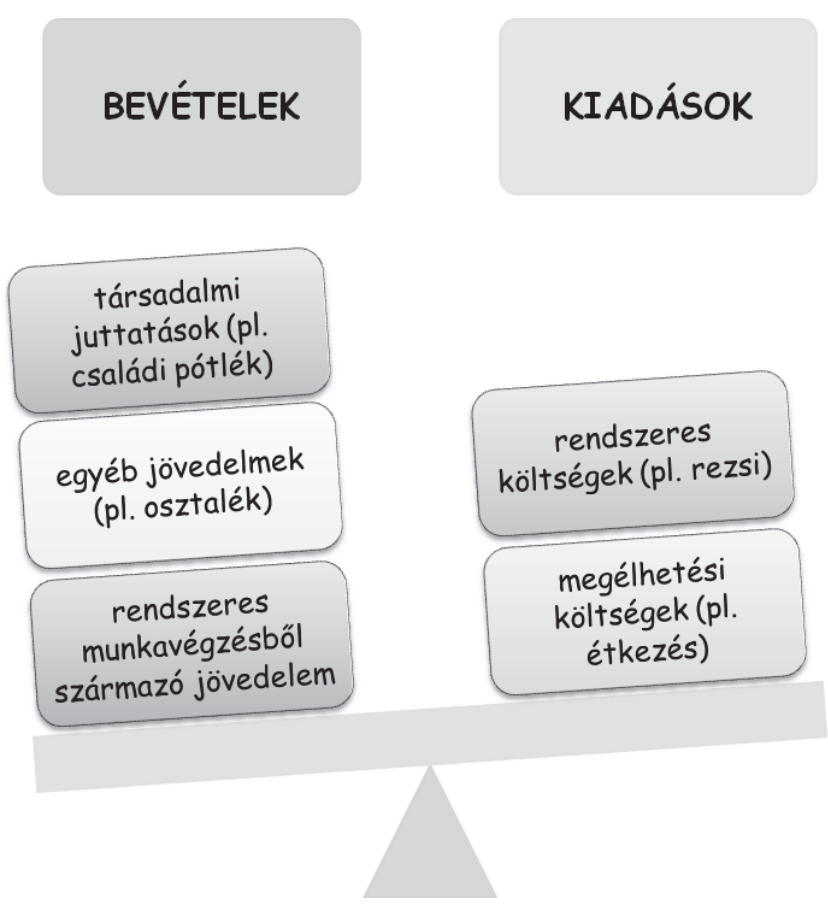

2. ábra: Családi költségvetés

\footnotetext{
3 Betétnek minősül az a hitelintézetnél elhelyezett pénzösszeg, amely pénz használatáért a bank kamatot fizet.
} 
Ezek után derül ki az is, hogy a fogyasztás után mekkora az az összeg, ami megtakarítható vagy egyáltalán marad-e belőle. Mindezt fontos minél részletesebben átgondolni és megtervezni, mivel ez megkönnyítheti a jövőbeni célok megvalósítását. Megkülönböztethetünk napi, heti, havi, illetve éves tervezést is, attól függően, hogy ki és milyen távlatban gondolkodik. Fel kell mérnünk a felmerülő összes költségeinket és bevételeinket az adott időszakra - ehhez azonban a család összes tagját külön-külön figyelembe kell venni - és úgy kell terveznünk, hogy a bevételeink haladják meg kiadásainkat. Legvégül a fennmaradó pénzmennyiség segítségével különféle megtakarításokra tehetünk szert, attól függően, kinek milyen tervei vannak előreláthatólag (CBA, 2014). A megtakarítások mérete növelhető, ha élünk a jogszabályok által nyújtott lehetőségekkel, kedvezményekkel is (adókedvezmény, járulékkedvezmény).
A háztartások öngondoskodásra való ösztönzése végett létrehoztak egy úgynevezett Családi Kasszasikerek Programot, ami a Provident Pénzügyi Zrt. által jött létre. Ennek célja, hogy a családok összefogásával növeljék az öngondoskodásra való hajlamot. E program 2008 júniusában jött létre, melynek azóta már számos tagja van. Úgy gondolták, hogy szükség van e program létrehozására, mivel a magyarok pénzügyi takarékoskodási képessége az eddigi felmérések szerint elég alacsony. A kampány alapértékei: a felelősség, az előrelátás, a gyarapodás, a biztonság és a megoldó készség (CSALÁDI KASSZASIKEREK, 2008).

Fontos azonban tisztában lenni azzal, hogy a befektetés és a megtakarítás nem egyforma jelentéssel bírnak, attól függetlenül, hogy a mindennapokban előfordul, hogy szinonímaként használjuk őket.

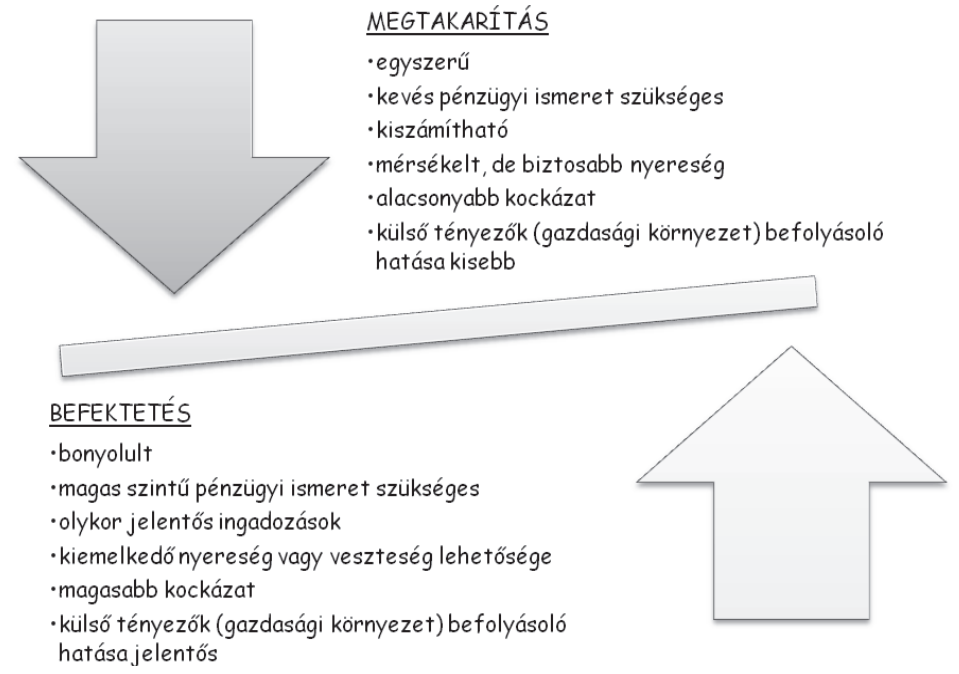

3. ábra: Megtakarítások és befektetések összevetése

Forrás: Pestiest különszám (2010)

Otthonteremtés gondolata

Manapság a felnőttek körében egyre nagyobb hangsúlyt kap a lakás-előtakarékosság. A lakáshoz jutás rendkívül nagy jelentőséggel bír, mivel ez a családalapítás alapja. Ez a folyamat nagy költségekkel jár, amihez szükség van biztos anyagi háttérre. Ezért nagy segítség lehet egy család számára, ha rendelkezik valamilyen 
megtakarítással. Kifejezetten erre a célra szolgálnak a különböző pénzintézeteknél megjelenő Lakástakarékpénztárak (LTP). Ez a szolgáltatásforma négy részre bontható: tartalmazza az összes betétet - a havi megtakarításokat, az állam által nyújtott támogatást, a betétre és az állami támogatásra jóváirt kamatot és az ehhez kapcsolódó lakáskölcsönt is. Ebből következően alaptevékenységének mondható a betétek gyújtése és a hitel nyújtása. Előnyei, hogy nem szükséges hozzá kezdő tőke. Ez egy állam által támogatott konstrukció. Emellett személy szerint, attól függően, hogy ki mekkora összeget tud erre havonta szánni, úgy lehet megválasztani a megtakarítás időtartamát. Azonban a lakáscélú hitel felvétele nem kötelező, de az állam lehetőséget ad rá. Felhasználását tekintve széles körben alkalmazható: például lakásépítésre, lakáskorszerűsítésre, felújításra, bővítésre, átépítésre és telekvásárlásra stb. Mindezt az 1996. évi CXIII. tv. 8.§ tartalmazza. Tehát ennek igénybevétele óriási lehetőséget nyújthat a jövőben elérendő lakáscélú szükségletek kielégítésére.

\section{Biztonság kialakításának fontossága}

A jövő megalapozása szempontjából egyre többen választják a biztosítók kínálta lehetőségeket, mivel bármikor bekövetkezhet egy olyan esemény, mely hirtelen nagyon nagy költségekkel jár, amit abban a pillanatban nem biztos, hogy bárki képes finanszírozni. Ehhez nyújtanak segítséget a különféle biztosítások. Általánosságban megkülönböztethetőek az élet-, illetve a nem életbiztosítások (lakás, autó, utazás stb.), melyek közül mindenki megtalálhatja igényeihez mérten a legmegfelelőbbet, mivel sokféle biztosítási termék jelent meg mostanáig: élet-, baleset-, és betegség biztosítások - melyek a halál vagy betegség esetén megkönnyítik azok finanszírozását; vagyonbiztosítások amennyiben káresemény jelentkezik, akkor azok térítésére szolgál; felelősségbiztosítások amikor a saját magunk által okozott károkat kellene finanszírozni. Előnyeinek mondható, hogy kockázatot a biztosító vállal, és amint egy olyan esemény következik be, melyre a megkötött szerződés vonatkozik, akkor a biztosító köteles fizetni. A biztosítás maga egyfajta megtakarítási módnak is tekinthető, azonban a biztosításoknak rendszeres díja van, amit következetesen fizetni kell ahhoz, hogy a majdani káreseményekre felhasználható legyen. Emellett a biztosító társaság kiválasztása többféle módon is történhet, amihez figyelembe kell venni a szerződési feltételeket, díjakat, kötelezettségeket is. A lényeg az, hogy alaposan át kell gondolni, hogy mire érdemes biztosítást kötni és mire nem. Ehhez fontos, hogy a biztosítás értéke arányban legyen a felmerülő kockázatok mértékével (CSALÁDI KASSZASIKEREK, 2008).

\section{Különböző takarékoskodási módok}

Sokak számára jelenthet bevételt a különböző pénztárak ügyes használata, mivel ezekbe a pénztárakba történő befizetések által számos előnyhöz lehet jutni. Az Önkéntes Kölcsönös Biztosító Pénztárakról szóló 1993. évi XCVI. törvény alapján három féle önkéntes pénztári szolgáltatás különböztethető meg: önsegélyező-, egészség-, illetve nyugdíjpénztár. Mindehhez tisztában kell lenni, hogy milyen funkciót látnak el ezek a pénztárak. A nyugdíj kiegészítéseként szolgáló megtakarítások azt a célt szolgálják, hogy a pénztár tagjai majd a nyugdíj elérésével a hosszú távú megtakarításait fel tudják használni. $A z$ egészségpénztárak pedig amellett, hogy egyfajta előtakarékossági funkcióval rendelkeznek, biztosítják az egészség megőrzése érdekében, hogy a pénztár tagjai finanszírozni tudják az ezzel kapcsolatos kifizetéseket. Az önsegélyező pénztárak szerepe abban rejlik, hogy bizonyos esetekben segítséget nyújtanak különféle szolgáltatások nyújtásával. Számos szolgáltatás vehető igénybe, csak tudni kell, hogy valamely esemény bekövetkeztekor, melyik pénztár által kínált lehetőséget használhatjuk ki. 


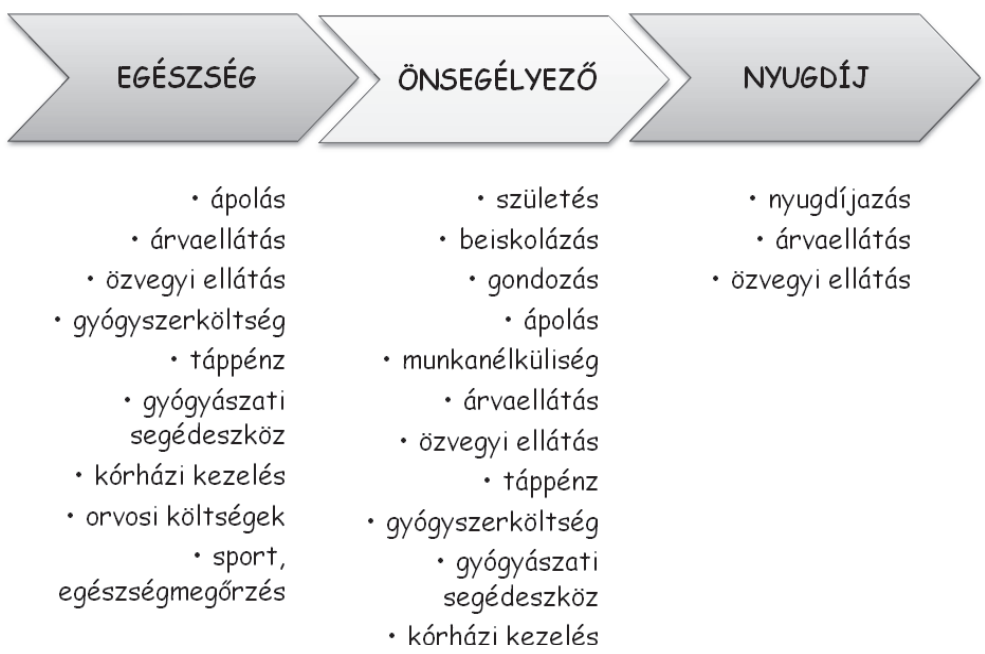

3. ábra: Az önkéntes pénztárak az igénybe vehető szolgáltatások alapján

Forrás: MATITS, 2005, p.3

A nyugdíjas évekre gondolva

Manapság különösen fontossá válik az időskorra való felkészülés. Mindez azért kerül középpontba, mert egyre nagyobb problémák merülnek fel: demográfiai változások mennek végbe - „elöregedik a társadalom”, miközben csökken a népességszám; a gazdasági helyzet bizonytalanabbá válik; emellett a háztartásokban nincsen pénzügyi egyensúly, vagyis a kiadások meghaladják a bevételek összességét. Sokat hallani mostanság, hogy a mai fiataloknak már mennyire bizonytalanná válhat a nyugdíjas évek anyagi háttere. Emiatt szükséges, hogy időben elkezdjenek takarékoskodni az időskori kiadásaikra.

\section{AZ IDŐSKOR ANYAGI HÁTTERE}

A nyugdíjba vonulás pillanatától fogva megkezdődik az addigi megtakarítások felélése és az előzőekből kiindulva ahhoz, hogy az addigi életszínvonal fennmaradjon, további megtakarításokra van szükség. Az idősek számára is számos lehetőség adódik még a takarékoskodásra, amennyiben van miből félretenni.
Már létrehoztak kifejezetten ilyen korúak számára bankszámlákat is, emellett a betétlekötés, különféle befektetési módok bárki számára elérhetőek, ráadásul a biztosító társaságok is rengeteg konstrukciót kínálnak. Ebben az esetben is az a lényeg, hogy mindenki magához mérten megtalálja a legkedvezőbb megtakarítási módot. Itt is szükség van arra, hogy a nyugdíjas éveiben is még naprakész legyen az ember, mivel alapos tervezést igényelnek ezek a takarékoskodási döntések.

\section{KUTATÁS EREDMÉNYEI}

Primer kutatást végeztünk, kérdőíves lekérdezés segítségével, amely során 620 fő töltötte ki a kérdőívünket Magyarország területéről. Külön megfigyeltük a gyermekek (018 év), fiatal felnőttek (19-25 év), az aktív felnőttek (26-62) valamint az idősek (63 év felett) véleményeit hazánk megtakarítási lehetőségeiről. Legtöbb választ (312 db) a fiatal felnőttektől, majd az aktív felnőttektől érkezett (274 db). Mindössze 24 gyermek és 10 idős személy töltötte ki kérdőívünket. 
A megkérdezett háztartások összetételüket tekintve 3 vagy több személyesek. A háztartások 10 százaléka csak egy főből áll, 26 százalékuk pedig jellemzően 2 személyesnek tekinthető. A legtöbb háztartás fő bevételi forráshoz rendszeres jövedelemmel jut hozzá, azonban sokak vállalnak alkalmi munkát még fóállás mellett is. A háztartások pénzügyeivel kapcsolatos kérdéseink alapján kiderült, hogy a legtöbben teljes mértékben fontosnak tartják a takarékoskodást, azonban a 620 főből tizenkettő személy szerint ez egyáltalán nem fontos a mai világban. Napjainkban élő családok többsége - 71 százaléka - elöre megtervezi pénzügyeit, melyhez van, aki készít családi költségvetést is (a válaszadók 39 százaléka).
Általában nem jellemző, hogy ehhez pénzügyi szakember segítségét vegyék igénybe.

A kitöltők között voltak olyanok is, akik egyáltalán nem rendelkeznek semmilyen felhalmozott pénzösszeggel sem, tehát e személyek úgymond „napról napra” élnek. Emellett felállítható egy sorrend attól függően, hogy ki milyen céllal kezdi el az el nem költött pénzét felhalmozni. Sokak leginkább azért gyújtögetnek, hogy fenntartsák családjuk anyagi biztonságát. Azonban számos dolog van, amire még félre kell, hogy tegyen az ember, melyek közül néhányat kiemelnénk egy ábra segítségével.

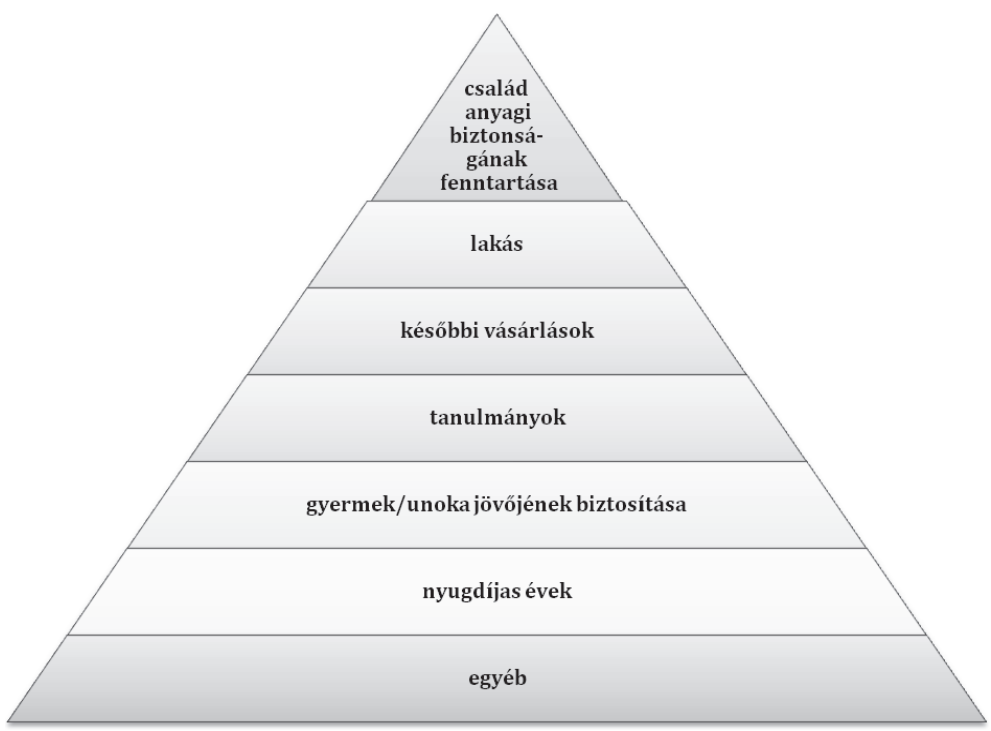

4. ábra: Célkitűzések megoszlása a megtakarítások terén

Forrás: Saját kutatás alapján, $N=620$

Akik gyermekük vagy unokájuk számára próbálnak megtakarítani leggyakrabban a pénzintézetek által kínált lehetőségek közül, 33 százalékuk a biztosítói intézmények kínálata közül választanak, azonban az állam által nyújtott segítséget - a babakötvényt - nagyon kevesen választják (mindössze 16 százalék). Sajnos sokszor adódik gond abból kifolyólag, hogy az információ mennyisége és minősége nem megfelelő. A válaszadók csupán 57 százaléka véli úgy, hogy elegendő információ áll rendelkezésére. Véleményünk szerint ez a nagy információhiány a megtakarítási szokásokon is észlelhető, mivel sokan tanácstalanok pénzügyeik terén. Úgy gondoljuk, a magyar lakosság pénzügyi kultúráját tekintve eléggé elmaradott, ezért ez a terület javításra szorul. Bővebb, a mindennapi ember számára is 
érthető és hasznos információkra lenne szükség, hogy mindenki tudatosabban tudja intézni családja pénzügyeit a könnyebb megélhetés érdekében.

\section{8. ÖSSZEFOGLALÁS}

"Mindenki a maga szerencséjének kovácsa" tartja a mondás, azonban napjainkban a szerencse már nem elég a létbiztonsághoz, a család és saját életünk anyagi stabilitásának megteremtéséhez. Fontos, hogy gondolkodásmódunkat úgy alakítsuk, hogy tudatosan előre tervezve készüljünk fel a saját és gyermekeink jövőjét anyagilag megalapozó, minőségi életet hozó jövőre.

Célszerű életciklusokra bontva vizsgálni a különböző megtakarítási és biztosítási lehetőségeket. A szülő feladata és kötelessége, hogy gyermeke jövőjét egyengesse, anyagi biztonságát megteremtse. Ehhez segítséget kaphat az államtól, a pénzintézetektől, illetve a biztosítási intézményektől. Az életkor előrehaladtával egyre több lehetőség nyílik további megtakarításokra, befektetésekre. A felnőttkor elérésével és a munkába állással a fiatal felnőtt jövedelemhez jut. Amennyiben jól gazdálkodik, a mindennapi kiadásai nem haladják meg a bevételeit, ezért bármilyen csekély kis megtakarítással, de már lehetősége nyílik vágyai eléréséhez. A felnőttkor csúcsán családalapításra gondolva a lakáshoz jutás pénzügyi alapjait is meg kell teremteni. Ehhez figyelembe kell venni a megtakarítási lehetőségeket: mekkora jövedelem áll rendelkezésre és ebból mekkora összeg az, amit kockázat nélkül leköthet vagy befektethet a minél magasabb hozam elérése érdekében. Ezt azonban több tényező is befolyásolja, legfőképpen az aktuális gazdasági helyzet és a társadalmi viszonyok. Előre gondolni kell a nyugdíjas évekre is. Olyan megtakarítási formát is kell keresni, mely az időskor anyagi biztonságát, az addigi életszínvonal megtartását teszi lehetővé. Mindezek eléréséhez rövid- és hosszú távú befektetések, biztosítással egybekötött megtakarítások, kockázatos, illetve kevésbé kockázatos pénzügyi megoldások keresése a cél, attól függően, hogy ki mire szeretné azt fordítani. Az állam által garantált értékpapírok vásárlásától kezdve egészen a tőzsdén keresztül, a különféle megtakarításokon át széles a paletta. Mindenki saját maga dönti el, hogy mely pénzügyi terméket választja, és igénybe veszi-e ennek eldöntéséhez pénzügyi szakemberek segítségét is.

Összefoglalva tehát megállapíthatjuk, hogy a pénzügyi tervezésre, a megfelelő gazdálkodásra, takarékosságra már gyermekkortól kellően oda kell figyelni. Ehhez fontos a példát mutató család szerepe, valamint a pénzügyi ismeretek gyakorlati használhatóságának oktatása már akár általános iskolás kortól (HORVÁTHNÉ KÖKÉNY, 2014). Így válhat megfontolt, pénzügyi szempontból is tudatos öngondoskodó felnőtté az ifjúság.

\section{FELHASZNÁLT IRODALOM}

[1] 1993. évi XCVI. törvény az Önkéntes Kölcsönös Biztosító Pénztárakról

[2] 2005. évi CLXXIV. törvény a fiatalok életkezdési támogatásáról

[3] 2005. évi CLXXXVII. törvény a lakás-takarékpénztárakról szóló 1996. évi CXIII. törvény módosításáról

[4] Balyó L. (2004) - A háztartás pénzügyei - Banki szolgáltatások igénybevétele háztartások által, https://felugyelet.mnb.hu/data/cms1571956/fv_tanul_haztart.pdf letöltés dátuma: 2014.05.17.

[5] Canadian Bankers Association (2014): Your budget - Take control of your financies letöltés dátuma: 2014.09.30. 
[6] Családi Kasszasikerek - Pénzügyi Öngondoskodás program (Nyugdíjrendszer) - letöltés dátuma: 2014.07.09.

[7] Családi Kasszasikerek - Pénzügyi öngondoskodás program (Nyugdíjrendszer) - letöltés dátuma: 2014.07.09.

[8] Horváthné Kökény A. (2014): Az állami szabályozás hatása a lakosság hosszú távú megtakarításaira, Doktori értekezés, https://szie.hu//file/tti/archivum/Horvathne_Annamaria_ertekezes.pdf, letöltés dátuma: 2014. 09.26.

[9] Matits Á. (2005): Az önkéntes pénztárak helyzete és jelentősége, Hitelintézeti szemle, 2005. évi különszám

[10] Nemzetközi Bankárképző Központ (2011): Az életciklus pénzügyei - avagy a háztartások pénzgazdálkodásához szükséges alapismeretek, http://www.ejam.hu/sites/default/files/kepek/pdf/fv_tanul_eletcikl.pdf, letöltés dátuma: 2014. 07.26.

[11] Pénzügyi Szervezetek Állami Felügyelete (2012): Megtakarítás a mindennapokban, 3. p. https://felugyelet.mnb.hu/data/cms2373704/Takarekossagi_vilagnap_20121031.pdf, letöltés dátuma. 2014. 08.12.

[12] Pénzügyi Szervezetek Állami Felügyelete (2013): Fogyasztóvédelmi osztály „Köznevelés” címú lap (2003. október 31.)

[13] Pénzügyi Szervezetek Állami Felügyelete (2014): http://www.pszaf.hu/fogyasztoknak/megtakaritasok/megtakaritasvalasztas/miertjo.html - letöltés dátuma: 2014.07.02.

[14] Pestiest különszám (2010), XIV. évfolyam 93. különszám: Megtakarítások, https://felugyelet.mnb.hu/data/cms2255509/PE_Megtakaritasok_2010.pdf letöltés dátuma: 2014.06.17. 